\title{
TEKNOLOGI MULTIMEDIA UNTUK PEMBUATAN BAHAN AJAR PADA GURU SMPIT BINA INSANI 1 SEMARANG
}

\author{
Mardiyono $^{\# 1, \text { Liliek Triyono }}{ }^{* 2}$, Prayitno ${ }^{\# 3}$, Sukamto ${ }^{\# 4}$, Tri Raharjo Yudantoro ${ }^{\# 5}$

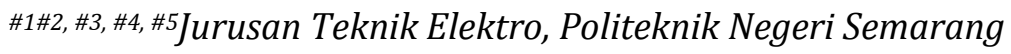 \\ Jl. Prof. H. Sudharto, S.H. Seamrang \\ \#1mardiyono@polines.ac.id, \#2liliek.triyono@gmail.com,\#3prayitnox@gmail.com, \\ \#4mr_sukamto@yahoo.com, \#5tryudan@yahoo.com
}

\begin{abstract}
ABSTRAK
Perkembangan teknologi pembelajaran berbasis multimedia menuntut para guru untuk menguasai dan menerapkannya dalam kegiatan belajar-mengajar di sekolah. Sayangnya masih banyak guru di SMP Islam Terpadu Bina Insani 1 Semarang yang belum menguasai pengetahuan dan kompetensi pembuatan bahan ajar berbasis multimedia dan ketersediaan pearlatan pendukung pembelajaran multimedia yang terbatas. Maka dari itu perlu dibuat suatu model kegiatan dalam bentuk program pelatihan dan penerapan teknologi multimedia dalam pembuatan bahan ajar para guru di sekolah tersebut. Tujuan dari kegiatan ini adalah membuat program pelatihan dan implementasi pembuatan bahan ajar berteknologi multimedia untuk memperkaya bahan ajar bagi para guru dan membantu penyediaan peralatan dan teknologi hardware dan software multimedia. Target yang diharapkan pada kegiatan ini meliputi: penguasaan teknologi multimedia pada bahan ajar lima orang guru, tersedianya tiga bahan ajar yang menggunakan teknologi multimedia. Metode yang digunakan terdiri dari empat tahap yaitu (1) observasi kebutuhan lapangan, (2)penyediaan peralatan pendukung multimedia, (3) pelatihan SDM, (4)pembuatan materi ajar multinedia. Berdasarkan hasil kegiatan yang telah dilakukan, luaran yang dihasilkan telah melebihi target yang direncanakan meliputi : 13 guru telah mengikuti pelatihan dan menguasai teknologi pembuatan bahan ajar multimedia, telah dihasilkan 10 materi ajar berbasis multimedia, dan tersedianya peralatan penunjang teknologi multimedia seperti laptop, access point, perangkat audio. Dampak dari kegiatan ini akan memperkaya metode pembelajaran para guru dengan teknologi multimedia sehingga memudahkan siswa dalam memahami materi pelajaran.
\end{abstract}

Keywords - guru, bahan ajar, multimedia, pelatihan

\section{PENDAHULUAN}

Sekolah Menengah Pertama Islam Terpadu (SMPIT) Bina Insani 1 yang baru berusia 2 tahun masih mempunyai banyak kekurangan, salah satunya adalah metode pembelajaran yang masih konvensional dan belum memanfaatkan teknologi multimedia. Hal ini bisa terjadi disebabkan belum tersedianya peralatan pendukung dan penguasaan kemampuan pembuatan bahan ajar berbasis multimedia. Padahal dengan menggabungkan metode konvensional dengan pembelajaran berbasis multimedia akan membuat suasana pembelajaran menjadi variatif dan dinamis yang berujung kepada meningkatnya pemahaman siswa terhadap materi yang diajarkan. Beberapa penerapan multimedia pembelajaran telah dilakukan oleh dipublikasikan (Budihariawan, Sudarma and Jampel, 2014), (Handayani and Ristrini, 2010), (Husain, Asrori and Endang, 2014), (Nuroeni, Syafik and Kurniawan, 2013), dan (Utami and Nugroho, 2013)

Sekolah ini terletak di Jl. Watukaji No 5A RT 03 RW VIII Kel. Gedawang Banyumanik Semarang yang merupakan satu-satunya SMP 
di kelurahan Gedawang. Sebenarnya hal ini menjadi faktor yang membuat motivasi lebih orang tua di wilayah Gedawang untuk menyekolahkan anaknya di SMP terdekat dengan lokasi rumah. Pada kenyataannya animo siswa yang mendaftar masih sedikit sehingga memerlukan evaluasi dari pihak pengelola untuk bisa menarik minat orang tua/siswa untuk mendaftar ke SMPIT Bina Insani 1. Salah satu metode unggulan pengajaran yang perlu menjadikan bahan pertimbangan adalah penyediaan bahan ajar ajar berbasis multimedia beserta sarana pendukungnya. Diharapkan dengan tersedianya fasilitas teknologi dan bahan ajar multimedia memudahkan siswa memahami materi/pelajaran dan ujung-ujungnya meningkatkan animo pendaftar. Penguatan kemampuan penguasaan bahan ajar berbasis multimedia mash terkendala dengan belum tersedianya alat pendukung dan kurangnya skill pembuatan bahan ajar multimedia. Hal ini memerlukan kegiatan pendampingan dalam bentuk pengabdian masyarakat.

Makalah ini membahas model program pelatihan dan penerapan teknologi multimedia untuk pembuatan bahan ajar pada sekolah SMPIT Bina Insani 1 Semarang. Makalah ini disusun dalam sistematika meliputi bagian satu pendahuluan dilanjutkan dengan sumber inspirasi pada bagian dua, metode dijelaskan pada bagian tiga, bagian empat menerangkan tentang karya utama dilanjutkan bagian lima tentang ulasan karya kemudian ditutup dengan kesimpulan pada bagian enam, serta dampak dan manfaat kegiatan pada bagian tujuh.

\section{TARGET DAN LUARAN}

Target utama dari kegiatan pengabdian masyarakat oleh tim pengabdian program studi Teknik Informatika jurusan Teknik Elektro ini adalah terdesiminasikan teknologi pembuatan bahan ajar dalam bentuk pelatihan kepada 5 guru di SMPIT Bina Insani 1 Semarang. Adapun target tambahan yang direncanakan adalah tersedianya peralatan pendukung multimedia, dan tersedianya 3 materi bahan ajar multimedia yang dibuat oleh para guru yang telah mendapatkan materi pelatihan.

Kegiatan ini telah menghasilkan luaran yang ternyata melebihi target yang direncanakan. Luaran yang telah dihasilkan berupa 13 guru telah menguasai teknologi pembuatan bahan ajar multimedia, 13 materi bahan ajar telah mampu diselesaikan oleh para guru, dan tersedianya bantuan perangkat pendukung teknologi multimedia meliputi laptop, software multimedia, access point, dan perangkat audio.

Disamping itu telah dihasilkan model kegiatan pelatihan pembuatan bahan ajar multimedia. Model ini bisa diterapkan untuk program kegiatan pelatihan pada kegiatan pengabdian atau penerapan teknologi pada masyarakat lainnya.

\section{METODE PELAKSANAAN}

Metode yang dilakukan untuk menyelesaikan permasalahan mitra meliputi 3 hal yaitu Pelatihan untuk meningkatkan pengetahuan dan skill pengajar, Penyediaan peralatan pendukung multimedia, dan Pembuatan bahan ajar multimedia. Penjelasan dari ketiga metode adalah sebagai berikut:

\section{A. Observasi kebutuhan lapangan}

Kegiatan ini sangat penting dilakukan untuk mengetahui sarana dan prasarana yang sudah ada serta metode pembelajaran yang sudah dilakuakan. Disamping itu untuk mengetahui penguasaan teknologi multimedia yang dimiliki para guru sehingga bisa menentukan materi pelatihan yang tepat.

\section{B. Penyediaan peralatan pendukung}

Peralatan pendukung sangat penting untuk penerapan pembelajaran berbasis multimedia. Perangkat yang dibutuhkan meliputi hardware dan software. Perangkat yang dibutuhkan meliputi laptop, wifi, audio, dan software multimedia.

\section{Pelatihan SDM}

Setelah peralatan sudah disediakan maka kegiatan selanjutnya berupa pelatihan 
guru sebanyak 5 orang tentang teknologi multimedia dan penggunaannya dalam mendukung pembelajaran. Penguasaan teknologi ini akan memperkaya guru dalam metode pembelajaran di kelas. Materi diberikan oleh para dosen prodi Teknik Informatika yang telah menguasai teknologi pembuatan bahan ajar multimedia.

\section{Pembuatan materi ajar multimedia}

Tahapan ini dilakukan untuk mengetahui sejauh mana para guru menyerap materi pelatihan yang telah diberikan. Para guru diberi tugas untuk membuat bahan ajar multimedia pada sub pokok bahasan pelajaran yang diampunya. Target yang dicapai dari tahapan ini berupa tersedianya 3 materi bahan ajar yang dibuat oleh para guru. Kontribusi mitra pada kegiatan ini ditunjukkan dengan menyediakan salah satu peralatan pendukung yaitu LCD. Mitra juga terlibat aktif dalam memberikan masukan dan saran terkait pelaksanaan kegiatan agar program pengabdian masyarakat ini berjalan dengan lancar. Disamping itu para guru bersedia untuk mengikuti pelatihan dan siap membuat bahan ajar berbasis multimedia untuk bisa diterapkan di lingkungan sekolah. Evaluasi kegiatan ini dilakukan dengan keberhasilan para guru dalam membuat bahan ajar multimedia untuk bisa diterapkan. Keberlanjutan program diteruskan dengan melakukan kegiatan pelatihan para guru untuk membuat animasi untuk mengilustrasikan materi pembelajaran yang diampunya seperti IPA, Matematika, Bahasa, Agama, dan lain-lain.

\section{KELAYAKAN PERGURUAN TINGGI}

Politeknik Negeri Semarang (Polines) sebagai perguruan tinggi vokasi selama ini aktif mentransfer IPTEK kepada masyarakat. Polines bekerjasama dengan Pusat Penelitian dan Pengabdian Kepada Masyarakat (P3M) menyelenggarakan pelatihan dan pembinaan/pendampingan usaha kepada masyarakat, sebagai contoh diantaranya:

- Pemanfaatan Energi Surya Sebagai Energi Alternatif Dan Peningkatan Media
Pembelajaran IPA Sekolah Alam Ar Ridho (2015)

- IbM Penerapan Pemasaran Produk Olahan Ikan Desa Wonosari, Kecamatan Bonang, Kabupaten Demak (2015)

- IbM Bagi Ukm Terasi Udang Di Kec. Wedarijaksa Pati (2015)

- IbM Pengrajin Batik Sekar Wangi Dan Batik Surya Kendal (2015)

- IbM pada Industri kuliner tradisional di desa wisata Kandri, Gunungpati, Semarang (2015)

- IbM Usaha Kerajinan Mebel Di Kecamatan Kalijambe Kabupaten Sragen(2015)

Polines memiliki staf pengajar yang kompeten dan berpengalaman dalam penerapan iptek. Tim pelaksana kegiatan pengabdian kepada masyarakat ini merupakan staf pengajar Politeknik Negeri Semarang, yang memiliki kompetensi sesuai dengan program yang dilaksanakan, selain dan mahasiswa akan terlibat aktif dalam kegiatan ini. Kepakaran yang diperlukan untuk menyelesaikan permasalahan mitra meliputi teknologi pembuatan bahan ajar berbasis multimedia yang didukung oleh 5 dosen Program Studi Teknik Informatika yang kompeten pada teknologi multimedia untuk pembuatan bahan ajar.

\section{HASIL DAN LUARAN YANG DICAPAI}

Model program yang dilaksanakan pada kegiatan ini terdiri dari beberapa komponen/unsur seperti peralatan (hardware), perangkat lunak (software), bahan-bahan ajar, para guru, instruktur pelatihan dosen Polines, serta program pelatihan. Gambaran dari model yang diterapkan pada kegiatan ini diperlihatkan pada Gambar 1.

Gambar 1 memperlihatkan model program pelatihan bahan ajar multimedia di SMPIT Bina Insani 1 Semarang. Bahan ajar yang disiapkan oleh para guru meliputi sub pokok bahasan pada mata pelajaran yang diampu seperti IPS, Bahasa Indonesia, Agama, IPA, dll. Bahan-bahan ini disiapkan dalam format slide power point. Guru-guru yang terlibat sebagai peserta merupakan para guru 
yang sudah menguasai pengoperasian sistem operasi windows dan program power point sedangkan instruktur adalah dosen Polines yang telah menguasai teknologi pembelajaran multimedia dan sudah menyiapkan materi pelatihan.

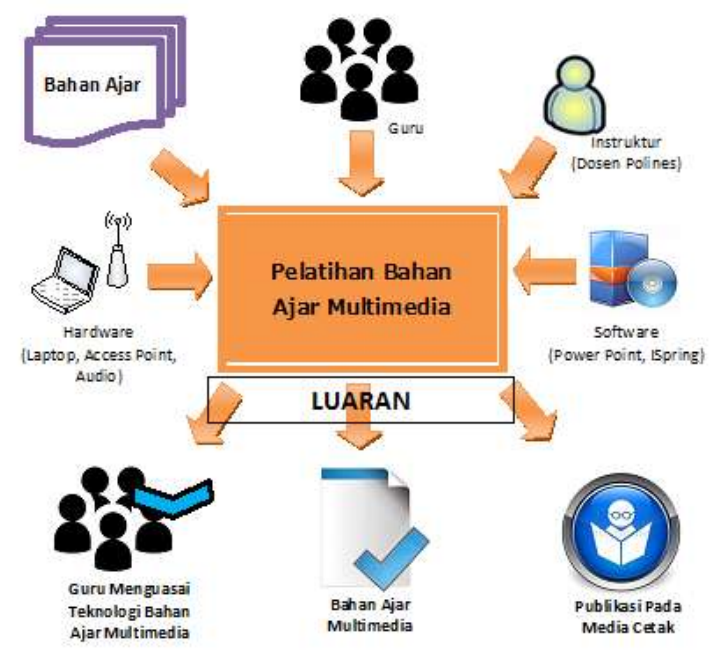

Gambar 1. Model Kegiatan Pelatihan bahan Ajar Multimedia

Unsur selanjutnya yang diperlukan adalah perangkat keras yang terdiri dari laptop, access point, dan perangkat audio seperti microphone dan speaker serta perangkat lunak berupa program power point dan ISpring. Kegiatan pelatihan pembuatan bahan ajar multimedia dilaksanakan satu hari selama 8 jam dengan materi pelatihan meliputi pengantar teknologi multimedia, penggunaan software multimedia, dan pembuatan bahan ajar berbasis multimedia. Luaran dari kegiatan berupa terkuasainya teknologi bahan ajar multimedia oleh para guru, tersedianya bahan ajar multimedia, dan publikasi pada surat kabar.

Kegiatan pelatihan dilaksakan pada tanggal 11 November 2017 di ruang kelas SMPIT Bina Insani 1 Semarang. Materi pertama tentang pengantar teknologi multimedia disampaiakan oleh Liliek Triyono, S. T., M. Kom. Materi yang dibahas meliputi bahan ajar, software-software pendukung multimedia, langkah-langkah menyiapkan bahan ajar multimedia, dan hal-hal yang harus dihindari pada pembuatan slide power point. Materi selanjutnya tentang pengoperasian software ISpring untuk membuat bahan ajar multimedia yang disampaikan oleh Prayitno, S.ST., M.T. Pada sesi ini disampaikan mengenai instalasi ISpring pada komputer, demo pembuatan slide power point dipadukan dengan penjelasan dalam bentuk video, dan konfigurasi pada publikasi (publish) bahan ajar multimedia dalam format exe yang bisa diputar pada komputer secara langsung. Setelah sesi pengoperasian software ISpring selesai, dilanjukan dengan praktikum dimana para peserta diberi tugas membuat bahan ajar multimedia pada komputer masingmasing. Sebelumnya para peserta menginstalasi program ISpring dan langsung mencobanya dengan mengintegrasikan rekaman video pada slide yang sudah dibuat. Kegiatan penyampaian materi pelatihan dan praktikum pembuatan bahan ajarnya diperlihatkan pada Gambar 2a, 2b, 2c, dan 2d.

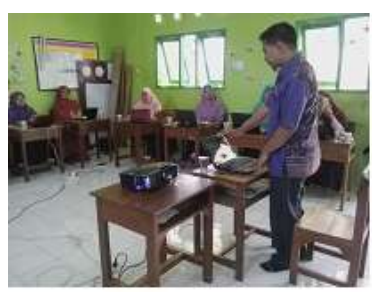

$2 \pi$

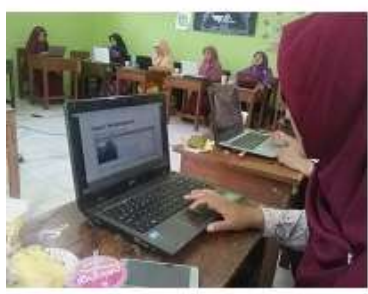

$2 s$

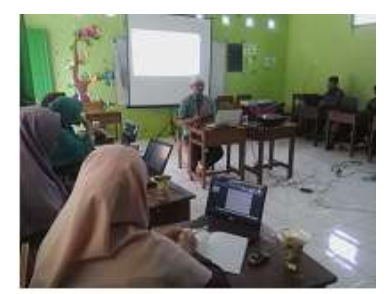

$2 \mathrm{~h}$

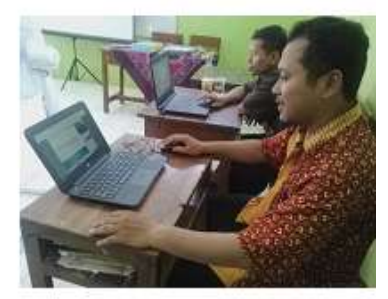

$2 A$
Gambar 2. Pelaksanaan Kegiatan Pengabdian

Gambar 2 menjelaskan tentang kegiatan pelatihan pembuatan bahan ajar multimedia di ruang kelas SMPIT Bina Insani 1 Semarang. Pada Gambar 2a dan 2b, instruktur dari Polines sedang menjelaskan materi pelatihan sedangkan gambar $2 \mathrm{c}$ dan $2 \mathrm{~d}$ menunjukan peserta yang sedang menjalankan program ISpring untuk memasukkan rekaman video pada slide presentasi dan 
mempublikasikannya dalam format file .exe. Dengan format .exe tersebut file yang dibuat dapat langsung diputar pada komputer.

Model pelatihan yang sudah dilakukan pada kegiatan pengadian masyarakat ini telah menghasilkan SDM guru yang menguasai teknologi pembuatan bahan ajar multimedia sejumlah 13 orang. Hal ini melampai target yang direncanakan yaitu 5 orang guru. Kenaikan peserta pelatihan menunjukan animo yang cukup besar dari para guru untuk mengikuti pelatihan ini. Pada akhir pelatihan telah diselesaikan bahan ajar multimedia sesuai pokok bahasan pembelajaran sejumlah 13 file yang menunjukkan bahwa para guru telah menguasai pengoperasian software ISpring dengan baik. Model pelatihan pembuatan bahan ajar memerlukan lima unsur meliputi guru, instruktur, bahan ajar, hardware, dan software. Durasi yang diperlukan 8 jam pelatihan dengan 3 materi yaitu pengantar teknologi multimedia, software multimedia, dan pembuatan bahan ajar multimedia. Luaran dari program ini yaitu 13 guru sudah menguasai teknologi bahan ajar multimedia, makalah, dan publikasi di media cetak. Software yang diperlukan yaitu Power Point dan ISpring sedangkan hardware yang diperlukan berupa PC/Laptop. Gambar 3 merupakan hasil karya salah satu guru yang sudah menyelesaikan pembuatan bahan ajar multimedia sedangkan Gambar 4 adalah hasil publikasi kegiatan pada media cetak Wawasan yang terbit hari Rabu, 15 November 2017.

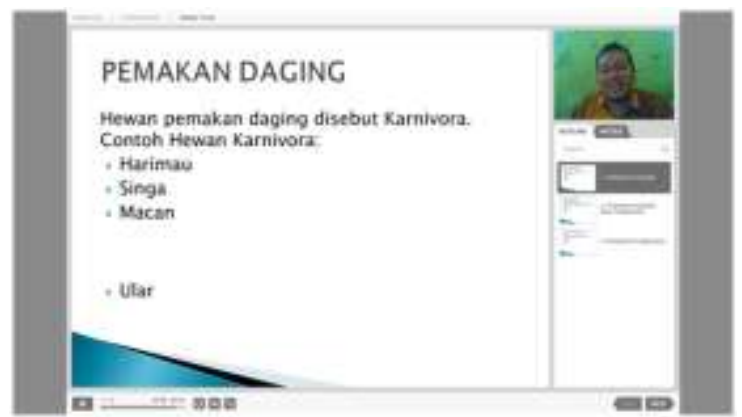

Gambar 3. Hasil karya salah satu peserta

Gambar 3 memperlihatkan hasil karya guru Pak Suroto yang bertemakan mata pelajaran ilmu pengetahuan alam. Dalam gambar terlihat bahwa perserta telah berhasil menggabungkan slide presentasi dengan video penjelasan di sebelah kanan atas. File yang dihasilkan dalam bentuk exe berteknologi Flash yang bisa langsung diputar pada komputer/laptop.

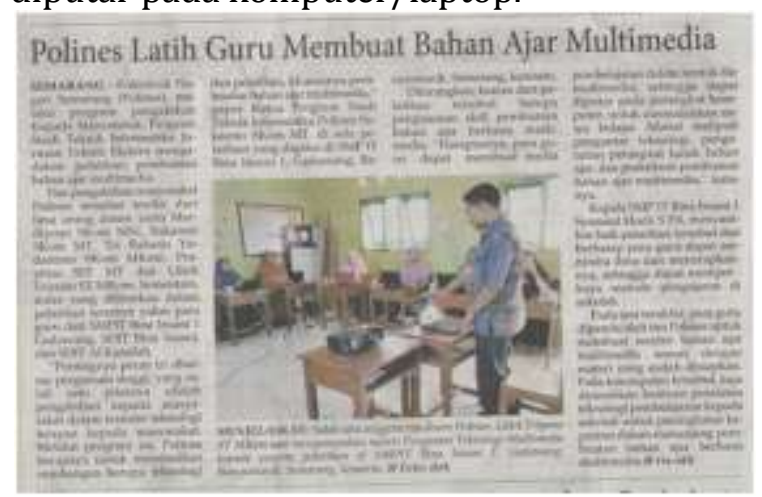

Gambar 4. Publikasi pada media cetak

Gambar 4 memperlihat hasil publikasi pada media cetak yang memperlihatkan salah satu instruktur pelatihan sedang menerangkan materi pengantar multimedia. Peserta para guru sangat antusias menyimak penjelasan dan mempraktekan pembuatan bahan ajar multimedia. Hal ini berdampak pada para guru telah menguasai teknologi pembuatan bahan ajar multimedia dengan terselesaikannya materi ajar multimedia pada pelatihan ini. Kegiatan ini juga memberikan bantuan alat penunjang teknologi multimedia kepada mitra. Bantuan peralatan yang diberikan meliputi laptop, software multimedia, access point, dan perangkat audio.

\section{KESIMPULAN DAN SARAN}

Pelatihan pembuatan bahan ajar multimedia telah dilaksanakan dan menghasilkan 13 guru menguasai teknologi bahan ajar multimedia menggunakan software power point dan ISpring. Disamping itu, telah diserahkankan pula bantuan peralatan teknologi multimedia untuk peningkatan kapasitas pembelajaran pada SMPIT Bina Insani 1 Semarang. Pengembangan model pelatihan dapat dilakukan dengan memperkaya materi 
pelatihan dengan software pembuat animasi bahan ajar sehingga siswa semakin jelas memahami ilmu yang diajarkan

\section{UCAPAN TERIMA KASIH}

Penulis mengucapkan terima kasih kepada Politeknik Negeri Semarang atas pembiayaan kegiatan ini melalui hibah pengabdian kepada masyarakat DIPA Unggulan Prodi serta SMPIT Bina Insani 1 sebagai mitra kegiatan dalam pelatihan teknologi multimedia pada pembuatan bahan ajar.

\section{DAFTAR PUSTAKA}

Budihariawan, I.M., Sudarma, I.K. and Jampel, I.N., 2014. Pengembangan Multimedia Interaktif pada Mata Pelajaran IPA untuk Kelas VII di SMP Negeri 2 Kubutambahan. Jurnal Edutech Undiksha, 2(1).

Handayani, L. and Ristrini, R., 2010. Pengaruh Model Pembelajaran Kesehatan Menggunakan Multimedia terhadap Perubahan Pengetahuan dan Sikap Siswa Sltp Terkait Faktor Risiko Penyakit
Jantung Koroner. Buletin Penelitian Sistem Kesehatan, 13(4 Okt).

Husain, F.N., Asrori, M. and Endang, B., 2014. Model Elaborasi Bahan Ajar Thaharah untuk Kecakapan Bersuci melalui Multimedia.Jurnal Pendidikan dan Pembelajaran, 3(10).

Nuroeni, R., Syafik, A. and Kurniawan, H., 2013. Pengembangan Multimedia Komik Pembelajaran Matematika Berbasis Kontekstual untuk Bahan Ajar KPK dan FPB. EKUIVALEN-Pendidikan

Matematika, 5(1), pp.89-96.

Riskiawan, H.Y., Setyohadi, D.P.S. and Arifianto, A.S., 2016. PELATIHAN PENGEMBANGAN MEDIA PEMBELAJARAN BERBASIS MULTIMEDIAUNTUK MENINGKATKAN KUALITAS DAN KREATIVITAS GURU SMA. J-Dinamika, 1(1).

Utami, S.S. and Nugroho, W., 2013. Pemanfaatan Bahan Ajar Sistem Informasi Akuntansi Berbasis Multimedia Interaktif. In Seminar Nasional Aplikasi Teknologi Informasi (SNATI) (Vol. 1, No. 1). 